BIOTROPIA NO. 25, 2005 : 50 - 59

\title{
PRODUCTION AND UTILIZATION OF CELLULASE FROM TRICHODERMA VIRIDE
}

\author{
R. HIDAYAT ${ }^{1}$, S. WULANDARI ${ }^{2}$, K.G. WIRYAWAN ${ }^{3}$ and SURYAHADI ${ }^{3}$ \\ ${ }^{1}$ Department of Animal Nutrition and Feed Science, Padjadjaran University, \\ Bandung, Indonesia. \\ ${ }^{2}$ Faculty of Animal Science, Jember Agricultural Polytechnique, Jember, Indonesia. \\ ${ }^{3}$ Department of Animal Nutrition and Feed Science, Bogor Agricultural University, \\ Bogor, Indonesia.
}

\begin{abstract}
An appropriate preservation technology for forage such as silage needs to be developed in order to overcome the shortage of tropical forage during the dry season. A good quality of silage is obtained by decreasing the fibre contents (Neutral Detergent Fibre, Acid Detergent Fibre and lignin). The research was conducted in two stages: 1). Production and activity test of crude enzymes from Trichoderma viride and 2). Comparative test using crude enzymes from Trichoderma viride strain QM 9414 (CETV) and commercial cellulase (Cellulase "Onozuka R-10", heidelberg) on rice straw silage. The treatments were arranged as follows : $\mathrm{P} 0=$ Untreated rice straw silage, $\mathrm{P} 1=$ Treated with commercial cellulase at $10 \mathrm{IU} \mathrm{kg}^{-1}$, $\mathrm{P} 2=$ Treated with CETV at $3.8 \mathrm{IU} \mathrm{kg}^{-1}, \mathrm{P} 3=$ Treated with CETV at $7.6 \mathrm{IU} \mathrm{kg}^{-1}$ and P4= Treated with CETV at $11.4 \mathrm{IU} \mathrm{kg}^{-1}$ of fresh rice straw. All treatments were enriched with $5 \%$ molasses. The result of the research indicated that: 1). The activity of crude enzymes from Trichoderma viride strain QM 9414 (CETV) was $1.52 \mathrm{IUml}^{-1}$. 2). The addition of both enzymes did not decrease dry matter of rice straw silage; however, organic matter significantly decreased $(\mathrm{p}<0.05)$ by addition of commercial cellulase. 3$)$. The addition of both enzymes decreased fibre contents (NDF), furthermore increased $(\mathrm{p}<0.05)$ in sacco digestibility of dry matter and organic matter of rice straw silage.
\end{abstract}

Keywords : Cellulase/Trichoderma viride/Rice straw/Silage/Fibre

\section{INTRODUCTION}

The main problem of improving ruminant production in Indonesia is the shortage of high quality forage during dry season causing the animal production become inefficient, because of an increase in feed cost. On the other hand, the forage is abundant during the wet season.

Application of forage preservation technology in the farm may solve the problem, as the forage becomes more available all the year. There are two forage preservation techniques namely dry preservation (hay) and wet preservation (silage). For some matters, ensiling has many advantages, as forage quality may be maintained for a few months. However, the silage production process still has weakness, as the dry matter decreases and the fibre content of the forage is not influenced by the process.

Rice straw is one of the agricultural by-products which is a very potential source of energy for ruminants. Availability of rice straw increases as the rice straw silage production increases. Rice straw is usually abundant at the same time as the 
BIOTROPIA NO. 25, 2005

period of high forage production occurring in the wet season. Farmers choose forage as feed rather than rice straw. Farmers store rice straw to be used during dry season when forage production is low. Rice straw as feed has been used generally in the tropic and sub-tropical areas (Jackson 1977), especially in the hot season. In Indonesia, rice straw has been used for feed at least 31-39\%, but most of it was burnt or used as fertilizer (36-62\%) and the rest is used for industries (Komar 1984).

Rice straw has low nutritive values. Rice straw contains $80 \%$ organic material which can be potentially digested; but in reality, it can be digested by ruminants only 45-50\% (Lubis 1963; Jackson 1977). According to Doyle et al. (1986), rice straw nutrient content is generally low consisting of crude protein 2.2-9.5\%, hemicelluloses $21-29 \%$, cellulose $35-49 \%$, with coefficient digestibility value of organic materials $31-59 \%$, and lignin $4-8 \%$. Dry storage condition (hay) makes the quality of rice straw becomes worse, therefore, a better method is needed to store the rice straw.

The present techniques in silage production are focused mainly on feed stuff preservation rather than improvement of its quality. It needs an effort to improve the process, and ensiling may be improved by both preservation and increase of the quality of forage.

Addition of enzymes as an active substance may disperse cell wall (NDF and ADF compounds) (Stokes and Chen 1994), increase digestibility and release the soluble carbohydrate portion of the forage. Enzymatic pre-hydrolysis of forage component may promote bacterial growth, enhance lactic acid production and decrease $\mathrm{pH}$ of silage (Bolsen and Sapienza 1993).

The present experiment is focused on application of commercial cellulase enzyme and crude enzyme produced by Trichoderma viride to improve nutritive value of rice straw.

\section{MATERIALS AND METHODS}

\section{Materials}

The materials used in this experiment were: Rice straw (cultivar IR 64), a commercial cellulase (Onozuka R-10 from Trichoderma viride with activity 1.0 $\mathrm{Umg}^{-1}$ produced by SERVA Electrophoresis GmbH D-69115 Heidelberg Carl-Benzstr.7) and Trichoderma viride strain QM 9414.

\section{Growth Media for Trichoderma viride}

Growth media composition that were used as substrates for Trichoderma viride to produce raw enzymes were : Media I, one litre media contains : $5 \mathrm{~g}$ $\mathrm{NH}_{4} \mathrm{NO}_{3}, 0.5 \mathrm{~g} \mathrm{KCl}, 0.01 \mathrm{~g} \mathrm{FeSO}_{4} .7 \mathrm{H}_{2} \mathrm{O}, 0.5 \mathrm{~g} \mathrm{MgSO} .7 \mathrm{H}_{2} \mathrm{O}, 0.001 \mathrm{~g} \mathrm{CuSO} \mathrm{C}_{4} .2 \mathrm{H}_{2} \mathrm{O}$, $1 \mathrm{~g}$ yeast extract and $6 \mathrm{~g}$ pepton ,the $\mathrm{pH}$ of media was 5.45. Media II, one litre media contains : $5 \mathrm{~g} \mathrm{NH}_{4} \mathrm{NO}_{3}, 0.5 \mathrm{~g} \mathrm{KCl}, 0.01 \mathrm{~g} \mathrm{FeSO}_{4} .7 \mathrm{H}_{2} \mathrm{O}, 0.5 \mathrm{~g} \mathrm{MgSO}_{4} .7 \mathrm{H}_{2} \mathrm{O}, 0.001 \mathrm{~g}$ $\mathrm{CuSO}_{4} \cdot 2 \mathrm{H}_{2} \mathrm{O}, 1 \mathrm{~g}$ yeast extract and $15 \mathrm{~g}$ rice straw. (Montesqrit 1998). 
Production and utilization of cellulose from Trichoderma viride - R. Hidayat et al.

\section{Experimental Design}

The research was conducted in two stages as follows:

Stage I: Production and activity test of crude enzymes from Trichoderma viride.

One loop of Trichoderma viride was cultured in a reaction tube containing 3-5 ml media I for four days and then it was transferred to an Erlenmeyer glass containing $250 \mathrm{ml}$ media II and incubated for 14 days with shaking. The crude enzymes were obtained by centrifugation at $4000 \mathrm{rpm}$, at $5^{0} \mathrm{C}$ for 30 minutes and the supernatant was used as an additive in the production of rice straw silage.

Stage II: A comparative test using crude enzymes from Trichoderma viride strain QM 9414 (CETV) and a commercial cellulase (cellulase "Onozuka R-10", Heidel-berg) on rice straw silage.

The experiment used completely randomized design with 5 replicates. A total of 25 silos with $1 \mathrm{~kg}$ per silo of fresh material were prepared. The treatments were based on enzyme activity and arranged as follows : $\mathrm{P} 0=$ Untreated rice straw silage, $\mathrm{P} 1=$ Treated with commercial cellulase at $10 \mathrm{IU} \mathrm{kg}^{-1}, \mathrm{P} 2=$ Treated with CETV at 3.8 IU kg ${ }^{-1}$, P3=Treated with CETV at $7.6 \mathrm{IU} \mathrm{kg}^{-1}$ and P4= Treated with CETV at 11.4 $\mathrm{IU} \mathrm{\textrm {kg } ^ { - 1 }}$ of fresh rice straw. All treatments were enriched with $5 \%$ molasses to provide ready available carbohydrate (RAC) as a stimulant fermentation. The $\mathrm{pH}$ before ensiling was normal.

\section{Silage Preparation}

The rice straw silage was made as many as $1 \mathrm{~kg}$ for each sample. The ensiling procedure is as follows: The rice straw was chopped into pieces of $\pm 5 \mathrm{~cm}$ length. The fresh and chopped rice straw was mixed with either commercial enzymes or crude enzymes from Trichoderma viride (spraying). The mixture was pressed and compacted by hand, and placed into a silo (glass jar). Then the silo was closed tightly so that the condition became free from $\mathrm{O}_{2}$, air and waterproof.

\section{Chemical Analysis}

Silage samples were collected for chemical analysis on the $30^{\text {th }}$ day of ensiling. The physical characteristics; colour, presence of fungi and smell of the silage were studied. Hence, the following parameters were measured : dry matter $(\mathrm{DM})$, organic matter $(\mathrm{OM})$, crude protein (CP) according to proximate analysis, $\mathrm{pH}$ (pH-Beckman model $\Phi$ 40). NDF, ADF and lignin content were analysed according to Van Soest and Wine (1967). Lactic acid was determined with an HPLC technique (Shimazu, Japan 3081-09202-20ATD-E). DM and OM digestibility were determined by nylon bag technique (in sacco) in a fistulated buffalo. The size of nylon bag is 140 x $90 \mathrm{~mm}$. One gram sample of silage was placed into nylon bag and incubated in the rumen for 24 hours. One week before and during the experiment, the buffalo was fed on $40 \mathrm{~kg}$ elephant grass and $5 \mathrm{~kg}$ rice bran per day. 


\section{Statistical Analysis}

The data were subjected to Analysis of Variance (ANOVA). When the F- test was significant $(\mathrm{P}<0.05)$, the contrast orthogonal test for paired comparisons was used.

\section{RESULTS AND DISCUSSIONS}

\section{Production and Activity Test of Crude Enzymes from Trichoderma viride}

On medium I, fungal growth was visible at the second day of cultivation. On medium II, fungal growth was detected at the second day which was shown by the mycelial growth in the media after transferred into Erlenmeyer glass. On the fourth day, the growth of mycelium was maximum and it was harvested. From 25 glasses of Erlenmeyer, 21 of them were harvested and others were thrown away because they were contaminated by unexpected micro-organisms or had imperfect growth.

The cellulase activity of crude enzymes from Trichoderma viride (CETV) was $1.52 \mathrm{IUml}^{-1}$. This result was higher than previous results (Montesqrit 1998) by the same procedure, which showed that the CMC-ase activity from $T$. viride fermented for 14 days was $0.673 \mathrm{IUml}^{-1}$. This was caused by a different strain of $T$. viride used, while the present experiment used T. viride strain QM 9414.

\section{Comparative Test Using Crude Enzymes From Trichoderma viride (CETV) and Commercial Cellulase on Rice Straw Silage.}

\section{The influence of treatments on the physical quality of rice straw silage}

Generally, rice straw silage had the same physical characters, either in colour, smell, texture or the presence of fungi. Rice straw silage had the same colour that was yellow brownish and moulds were seen on the top of the silage. The colour of silage was not different from the fresh rice straw.

The silage had good smell, fresh and crumb texture for all treatments. It showed that the fermentation had taken place by producing lactic acid. The utilization of dry rice straw as silage material also had positive impact on silage quality i.e. the silage liquid was little and there was not much soluble nutrient wasted into silage liquid. Other reports indicated that making silage in wet condition produced much liquid (McDonald et al.1991), so dryer condition was needed to make easy handling and produced higher and drier silage. 


\section{The influence of treatments on the chemical quality of rice straw}

\section{Nutrients content of rice straw silage}

Table 1 presents the nutrients content of rice straw silage. The dry matter content of rice straw silage treated with enzymes (P1, P2, P3 and P4) was not significantly different from dry matter of untreated rice straw silage. This result was different from rice straw directly treated by $T$. viride in which it caused degradation of rice straw dry matter $8.4 \%$ (Soetjiharto 1997). However, dry matter of rice straw silage treated by commercial enzymes was significantly $(\mathrm{p}<0.05)$ reduced compared to that of silage treated by CETV.

Table 1. Nutrient content of rice straw silage

\begin{tabular}{lccccc}
\hline \hline \multirow{2}{*}{ Nutrients } & \multicolumn{5}{c}{ Treatments } \\
\cline { 2 - 6 } & P0 & P1 & P2 & P3 & P4 \\
\hline Dry matter (\%) & $24.3 \pm 0.4$ & $23.9 \pm 0.6$ & $24.6 \pm 0.1$ & $24.6 \pm 0.2$ & $24.9 \pm 0.6$ \\
Organic Matter (\%) & $79.1 \pm 0.2$ & $79.2 \pm 0.2$ & $79.2 \pm 0.3$ & $79.6 \pm 0.1$ & $79.5 \pm 0.4$ \\
Crude protein (\%) & $5.9 \pm 0.5$ & $5.8 \pm 0.3$ & $5.4 \pm 0.2$ & $5.3 \pm 0.3$ & $5.6 \pm 0.3$ \\
\hline
\end{tabular}

P0=Untreated rice straw silage, P1=Treated with commercial cellulase at $10 \mathrm{IU} \mathrm{kg}^{-1}, \mathrm{P} 2=$ Treated with CETV at $3.8 \mathrm{IU} \mathrm{kg}^{-1}, \mathrm{P} 3=$ Treated with CETV at $7.6 \mathrm{IU} \mathrm{kg}^{-1}$ and P4= Treated with CETV at $11.4 \mathrm{IU} \mathrm{kg}^{-1}$ of fresh rice straw.

Organic matter content of rice straw silage treated with enzymes (P1, P2, P3 and $\mathrm{P} 4)$ was $79.4 \%$, and higher $(\mathrm{p}<0.05)$ compared with control $(\mathrm{P} 0=79.1 \%)$. This result was different from direct microbiological treatment as stated by Djunaidi (1988) that organic matter content of rice straw silage put on the ground was descending. Organic matter content of rice straw silage treated with commercial enzymes (79.2 \%) was not significantly different from organic matter of rice straw silage treated with CETV (P2, P3, and P4 = 79.4\%). It was different from Stokes and Chen (1994) observation that the increase of commercial cellulase addition to corn silage decreased the silage organic matter content.

Crude protein of rice straw silage treated with enzymes (P1, P2, P3 and P4) was $5.5 \%$ and significantly lower $(\mathrm{p}<0.05)$ than crude protein of untreated rice straw silage $(\mathrm{P} 0=5.9 \%)$. This was caused by CETV which still contained protease, so that some crude protein of rice straw was degraded to become ammonia. A different result was reported by Stokes and Chen (1994) in which crude protein content of corn silage treated with commercial cellulase was increased. This was caused by microorganism growth as source of protein.

\section{Fibre content of rice straw silage}

The effects of addition of commercial cellulose and CETV to fibre content of rice straw silage are presented in Table 2. The Neutral Detergent Fibre (NDF) 
content of rice straw silage treated with enzymes (P1, P2 ,P3 and P4) was $72.3 \%$, and significantly lower $(\mathrm{p}<0.05)$ compared to untreated silage $(\mathrm{P} 0=79.0 \%)$. Reduction of NDF content of rice straw silage treated with CETV followed the equation of $\mathrm{Y}=77.75-1.37 \mathrm{X}$. Corn silage treated with cellulase had lower NDF content (46.7\%) compared to untreated corn silage $(53.1 \%)$ (Stokes and Chen 1994).

There is no significant difference $(\mathrm{p}<0.05)$ between Acid Detergent Fibre (ADF) content of rice straw silage treated with enzymes (P1, P2 ,P3 and P4=56.2 \%) and control $(\mathrm{P} 0=59.5 \%)$, but the ADF content of rice straw silage treated with enzyme tended to be lower $(\mathrm{p}<0.05)$ than $\mathrm{ADF}$ content of untreated rice straw. Enzyme treatment decreased ADF content of rice straw silage about $5.6 \%$ from control.

Table 2. Fibre content of rice straw silage

\begin{tabular}{lcccccc}
\hline \hline & \multicolumn{7}{c}{ Treatments } \\
\cline { 2 - 7 } & P0 & P1 & P2 & P3 & P4 & Significance \\
\hline NDF (\%) & $79.0 \pm 3.4$ & $76.4 \pm 1.2$ & $74.2 \pm 2.7$ & $71.2 \pm 3.1$ & $67.4 \pm 2.9$ & P $<0,05$ \\
ADF (\%) & $59.5 \pm 4.4$ & $59.2 \pm 2.9$ & $57.6 \pm 7.6$ & $53.6 \pm 2.7$ & $54.2 \pm 2.1$ & NS \\
Lignin (\%) & $7.7 \pm .0 .8$ & $8.4 \pm .1 .7$ & $6.6 \pm .1 .7$ & $6.2 \pm .1 .5$ & $5.7 \pm .0 .5$ & NS \\
\hline
\end{tabular}

NDF $=$ Neutral Detergent Fibre, $\mathrm{ADF}=$ Acid Detergent Fibre, $\mathrm{P} 0=$ Untreated rice straw silage, $\mathrm{P} 1=$ Treated with commercial cellulase at $10 \mathrm{IU} \mathrm{kg}^{-1}, \mathrm{P} 2=$ Treated with CETV at $3.8 \mathrm{IU} \mathrm{kg}^{-1}, \mathrm{P} 3=$ Treated with CETV at $7.6 \mathrm{IU} \mathrm{kg}^{-1}$ and P4= Treated with CETV at $11.4 \mathrm{IU} \mathrm{kg}^{-1}$ of fresh rice straw.

The Acid Detergent Fibre (ADF) content of rice straw silage treated with CETV (P2, P3, and P4) was $55.1 \%$, and it was not significantly different from ADF content of rice straw silage treated with commercial enzyme $(\mathrm{P} 1=59.2 \%)$. This result was different from that reported by Stokes and Chen (1994), that ADF content of corn silage treated by commercial enzyme decreased about $11-13 \%$. It appears that ADF content of rice straw silage treated with CETV was lower compared with commercial enzyme treatment. This means that CETV had higher potential than commercial cellulase in degrading ADF of rice straw silage. Rice straw is difficult to be degraded because rice crop is harvested at mature stage with high cell wall content and perfect lignification level.

The lignin content of rice straw silage treated with enzymes (P1,P2,P3 and P4= $6.6 \%)$ was not different from control (7.7\%). However, the content of rice straw silage lignin treated by commercial enzyme $(\mathrm{P} 1=8.4 \%)$ was significantly higher compared with that treated by CETV (6.2\%).

The decrease in lignin content by CETV treatment might be caused by: crude enzymes CETV which possess many enzymatic activities including lignase, and production of organic acid during ensilage. 
Lignin can be depolymerised by microbial enzymes produced by Trichoderma sp. (Paterson 1986). On the other hand, commercial enzyme is purely cellulase enzyme that has no lignase activities, so increasing the level of commercial enzyme did not affect the lignin content of rice straw silage.

3. ph and lactic acid production of rice straw silage

There were no differences between $\mathrm{pH}$ of rice straw silage treated with enzyme $(\mathrm{P} 1, \mathrm{P} 2, \mathrm{P} 3$ and $\mathrm{P} 4=3.72)$ than that of control $(\mathrm{P} 0=3.72)$. This result is in line with Stokes and Chen (1994) who reported that enzyme application has no effect to corn silage $\mathrm{pH}$. Nevertheless, rice straw silage $\mathrm{pH}$ treated with commercial enzyme (P1 = 3.68) had significantly lower $(\mathrm{P}<0.05) \mathrm{pH}$ than rice straw silage treated by CETV (3.73). The effect on the addition of commercial cellulase and CETV to $\mathrm{pH}$ and lactic acid production of rice straw silage is presented in Table 3.

Table 3. $\mathrm{pH}$ and Lactic Acid Production of rice straw Silage

\begin{tabular}{lcccccc}
\hline \hline & \multicolumn{7}{c}{ Treatments } \\
\cline { 2 - 7 } & $\mathrm{P} 0$ & $\mathrm{P} 1$ & $\mathrm{P} 2$ & $\mathrm{P} 3$ & $\mathrm{P} 4$ & Significance \\
\hline Lactic Acid (\%) & $0.23 \pm 0.05$ & $0.35 \pm 0.04$ & $0.27 \pm 0.01$ & $0.26 \pm 0.03$ & $0.25 \pm 0.04$ & $\mathrm{P}<0.05$ \\
$\mathrm{pH}$ & $3.72 \pm 0.03$ & $3.68 \pm 0.02$ & $3.71 \pm 0.01$ & $3.75 \pm 0.01$ & $3.74 \pm 0.02$ & $\mathrm{NS}$ \\
\hline
\end{tabular}

$\mathrm{P} 0=$ Untreated rice straw silage, $\mathrm{P} 1=$ Treated with commercial cellulase at $10 \mathrm{IU} \mathrm{kg}^{-1}, \mathrm{P} 2=$ Treated with CETV at $3.8 \mathrm{IU} \mathrm{kg}^{-1}, \mathrm{P} 3=$ Treated with CETV at $7.6 \mathrm{IU} \mathrm{kg}^{-1}$ and $\mathrm{P} 4=$ Treated with CETV at $11.4 \mathrm{IU} \mathrm{kg}^{-1}$ of fresh rice straw.

$\mathrm{pH}$ of rice straw silage treated with commercial enzyme had the lowest $\mathrm{pH}$. This was related to silage lactic acid production, where silage treated with commercial enzyme had the highest concentration of lactic acid (0.35 \%). Rice straw silage $\mathrm{pH}$ treated with CETV tended to increase as the enzyme levels were increased. This might be due to a carry-over of some buffers from the media of Trichoderma viride during centrifugation for enzyme preparation. In addition, protease activity of CETV could degrade protein into ammonia. The increase in $\mathrm{pH}$ of rice straw silage treated with CETV follows the linear equation of $\mathrm{Y}=3.696+$ $0.0072 \mathrm{X}$. In general, rice straw silage $\mathrm{pH}$ was very good, i.e. under 4 . This means that rice straw silage can be stored in silos for a long time. Good silage had $\mathrm{pH}$ between 3.5 and 4.0 (AAK 1983).

Lactic acid production of rice straw silage treated with enzyme (P1, P2, P3 and P4) was $0.29 \%$ higher than the control ( $\mathrm{P} 0=0.25 \%$ ). Addition of enzyme could improve lactic acid production of rice straw silage. Low moisture content probably influenced the relative growth of homofermentative and heterofermentative lactic acid bacteria during ensiling, which in turn lowered the $\mathrm{pH}$ of silage, minimizing 
BIOTROPIA NO. 25, 2005

deterioration (McDonald et al. 1991). A different result was reported by Man and Wiktorsson (2002) in which lactic acid production of cassava and gliricidia tops silage was $0.95-0.99 \%$, respectively.

Lactic acid concentration of rice straw silage treated with commercial enzyme ( $\mathrm{P} 1=0.35 \%)$ was significantly higher than lactic acid concentration of rice straw silage treated with CETV (P2,P3 and P4=0.26 \%). The lactic acid concentration was parallel to rice straw silage $\mathrm{pH}$. The higher production of lactic acid, the lower became the silage $\mathrm{pH} . \mathrm{pH}$ of rice straw silage treated with commercial enzyme was the lowest. While the $\mathrm{pH}$ of rice straw silage treated with CETV increased parallelly to CETV dosages.

\section{Digestibility of Dry Matter and Organic Matter of Rice Straw Silage}

The digestibility of dry matter (DDM) of rice straw silage treated with enzyme (P1, P2, P3 and P4=37.5\%) was significantly higher than the digestibility of dry matter of untreated rice straw silage $(\mathrm{P} 0=28.0 \%)$. A similar result was obtained for digestibility of organic matter (DOM) (Table 4.). The increased degradation might have to do with the increased damage of feed surface caused by exogenous enzyme treatment of feed before feeding (Nsereko et al. 2000). Hong et al. (2003) stated that nutrient degradation rate and effective degradability of DM increased by addition of enzyme mixture consisting of mainly cellulase and xylanase. The enzyme applied to forages immediately before in vitro incubation also improved digestion of DM and NDF, suggesting that fibrolitic enzymes applied for feeding (direct fed) may enhance digestion of forage by cattle (Feng et al. 1996). Beauchemin et al. (2001) reported that applying fibrolytic enzymes prior to feeding enhances ruminal fibre digestion by altering the structure of the feed, thereby making it more susceptible to degradation. Exogenous enzymes treatment, prior to ingestion, increase bacterial colonization and thereby improves DM disappearance of forage (Yang et al. 1999) because exogenous enzymes increased microbial attachment of ruminal microbes to feed and increased activity of enzymes associated with feed particles (Wang et al. 2001).

The digestibility of dry matter of rice straw silage treated by CETV (P2, P3 and $\mathrm{P} 4=37.1 \%$ ) was not significantly different from the digestibility of dry matter of rice straw silage treated with commercial enzyme ( $\mathrm{P} 1=38.8 \%)$.

The improvement in the digestibility of silage treated with enzymes was caused by decreasing NDF, ADF and lignin content in the silage. Decreasing fibre content (ADF and NDF) and lignin of rice straw silage made the silage easier to be degraded by rumen microbes.

The increase of DDM of rice straw silage treated with CETV followed the linear equation of $\mathrm{Y}=21.31+3.14 \mathrm{X}$. Meanwhile, DOM followed the equation of $\mathrm{Y}=17.43+3.46 \mathrm{X}$. It showed that CETV dosage had not reached the maximum level as the digestibility was still increasing. 
Production and utilization of cellulose from Trichoderma viride - R. Hidayat et al.

Table 4. Digestibility of Dry Matter and Organic Matter of Rice Straw Silage

\begin{tabular}{ccc}
\hline \hline Treatments & Digestibility of Dry Matter (\%) & Digestibility of Organic Matter (\%) \\
\hline P0 & $28.6 \pm 3.3$ & $25.6 \pm 3.6$ \\
P1 & $38.8 \pm 2.5$ & $36.8 \pm 2.6$ \\
P2 & $28.3 \pm 2.0$ & $25.0 \pm 2.5$ \\
P3 & $38.9 \pm 1.3$ & $37.0 \pm 1.7$ \\
P4 & $44.0 \pm 3.5$ & $42.3 \pm 4.0$ \\
\hline
\end{tabular}

$\mathrm{P} 0=$ Untreated rice straw silage, $\mathrm{P} 1=$ Treated with commercial cellulase at $10 \mathrm{IU} \mathrm{kg}^{-1}, \mathrm{P} 2=$ Treated with CETV at $3.8 \mathrm{IU} \mathrm{kg}^{-1}, \mathrm{P} 3=$ Treated with CETV at $7.6 \mathrm{IU} \mathrm{kg}^{-1}$ and P4= Treated with CETV at $11.4 \mathrm{IU} \mathrm{kg}^{-1}$ of fresh rice straw. Digestibility of dry matter (DDM) and organic matter (DOM) of rice straw silage treated with enzyme (P1, P2, P3) was significantly higher than digestibility of dry and organic matter of untreated rice straw silage (P0).

The present study clearly indicates that the most promising method to improve the nutritive value of agricultural by-products in terms of increasing the digestibility is to treat rice straw with cellulase enzyme addition during ensiling.

\section{CONCLUSIONS}

Fungi of Trichoderma viride strain QM9414 produced crude enzymes with high cellulolytic activity i.e. $1.52 \mathrm{IU} / \mathrm{ml}$. CETV was able to improve the biological value of rice straw silage and it was better than commercial cellulase. Addition of commercial cellulase (Onozuka R10 from Trichoderma viride ) and crude enzymes from Trichoderma viride (CETV) have positive influence on physical quality of rice straw silage and did not cause negative effect on dry matter and organic matter content of rice straw silage.

\section{ACKNOWLEDGEMENT}

The researcher would like to thank SEAMEO SEARCA for financing this research.

\section{REFERENCES}

AAK. 1983. The Forage. Yayasan Kanisius. Yogyakarta.

Beauchemin, K.A., D.P. Morgavi, T.A. McAllister, W.Z. Yang and L.M. Rode. 2001. The use of enzymes in ruminant diets. In: Recent Advances in Animal Nutrition (Ed. P.C. Garnsworthy and J. Wiseman). Nottingham University Press. Nottingham. p. 298-322.

Bolsen, K. K., Sapienza. 1993. Silage Technology. Planting, making and feeding to the livestock. Pioneer Seeds. USA. 
BIOTROPIA NO. 25, 2005

Djunaidi, I.H. 1988. Improvement of rice straw through degradation of fungi. Bogor Agricultural University, Bogor (Desertation).

Doyle, P.T., C. Devendra, G.R. Pearce. 1986. Rice straw as a feed for ruminant. IDP, Australian Universities and College, Canbera.

Feng, P., C.W. Hunt, G.T. Pritchard and W.E. Julien. 1996. Effect of enzyme preparations on in situ and in vivo degradation and in vivo digestive characteristics of mature cool-season grass forage in beef steers. J. Anim. Sci. 74:1349-1357.

Hong, S.H., B.K. Lee, N.J. Choi, S.S. Lee, S.G. Yun and J.K. Ha. 2003. Effect of enzyme application method and levels and pre-treatment times on rumen fermentation, nutrient degradation and digestion in goats and steers. Asian-Aust.J.Anim.Sci. Vol 16, No. 3:389-393.

Jackson, M.G. 1977. The alkali treatment of straw, Anim. Feed Sci. and Tech. 2:105-130.

Komar, A. 1984. Technology of rice straw preservation as feed. Yayasan Dian Grahita. Indonesia, Bandung.

Lubis, D.A. 1963. Feed Science. Yayasan Pembangunan Jakarta.

Man, N.V. and H. Wiktorsson. 2002. Effect of molasses on nutritional quality of cassava and gliricidia tops silage. Asian-Aust. J. Anim. Sci. 5(9):1294-1299.

McDonald, P., A.R. Henderson., S.J.E. Heron. 1991. The Biochemistry of Silage. Chalcombe Publication, 13 Highwoods drive, Mariow Bottom, Marlow, Bucks SL73PU.

Montesqrit, 1998. Cellulase extraction from the mold and its application to improve fibrous waste product for ruminant. M.Sc. Thesis. Post Graduate Programe. Bogor Agricultural University. Bogor.

Nsereko, V.L., D.P. Morgavi, K.A. Beauchemin and L.M. Rode. 2000. Inhibition of ruminant feed enzyme polysaccharidase activities by extracts from silage. Can. J. Anim. Sci. 80:523-526.

Paterson, A. 1986. Biodegradation of lignin and cellulosic material. Expert Consultation on Biotechnology for livestock Production and Health. Rome. AGA:Biot/86/24.

Soetjiharto, M. 1997. Isolation of mold-degrading lignocellulase and its application to improve nutritive value of fibrous feed. Bogor Agricultural University. Bogor

Stokes, M.R. and J. Chen. 1994. Effect of enzyme-inoculant mixture on the course of fermentation of corn silage. J. Dairy Sci. 77:3401-3409.

Van Soest, P.J., R.H. Wine. 1967. Use of detergents in the analysis of fibrous feeds. IV. Determination of plant cell wall constituents. J. Assoc. of Anal. Chem., 50:50.

Wang, Y., T.A. McAllister, L.M. Rode, K.A. Beauchemin, D.P. Morgavi, V.L. Nsereko and A.D. Iwaasa. 2001. Effect of an exogenous enzyme preparation on microbial protein syntesis, enzyme activity and attachment to feed in the rumen simulation technique (rusitec). Br. J. Nutr. 85:325-332.

Yang, W.Z., K.A. Beauchemin and L.M. Rode. 1999. Effect of enzyme feed additives on extent of digestion and milk production of lactating dairy cow. J. Dairy Sci. 82:391-403. 